\title{
Namophila HYACINTHACEAE
}

\author{
U. Eggli
}

Namophila U. \& D. Müller-Doblies (Feddes Repert. 108(1-2): 77-79, ills., 1997). Type: Namophila urotepala U. \& D. Müller-Doblies. - Hyacinthoideae - Massonieae - Lit: Martínez-Azorín \& al. (2015: classification). Distr: S Namibia. Etym: Gr. 'nama', spring, stream; and Gr. 'philos', friend; for the occurence in a valley with a seasonal stream.

Bulbous geophytes to $5 \mathrm{~cm}$ tall, bulbs usually solitary, globose, $1.5-2.3 \mathrm{~cm} \varnothing$; L 2, ovate, $11-16 \times 8-11.7 \mathrm{~cm}$, (sub-) succulent, prostrately spreading; Inf 1, corymbose-capitate, between the leaves, 2- to 3-flowered (to 19-flowered in cultivation), raceme 1-4 cm; Bra linear, inconspicuous, lowest 17-36 × (1.3-) 2.5-3.5 mm; Ped $7-18 \mathrm{~mm}$; Fl stellate, green, to $33 \mathrm{~mm} \varnothing$; Tep 19-23 mm, basally united and forming a 4-6 mm long tube, lobes (12-) 15-17 × 3.5-4.5 mm, narrowly triangular, with a distinctly caudate tip 1-4.7 mm long; St basally fused to the tepal tube; free part of Fil 6-8 mm, white; Anth 2-2.5 mm, green with yellow pollen; Ov obclavate, green, 3.5-5 × 3-3.7 mm; Sty 8-10 mm, green; Sti punctiform; Fr enveloped by the fleshy perianth, $10 \mathrm{~mm}$; Se globose, $2 \times 1.2-1.8 \mathrm{~mm}$, black, glossy.

The monotypic genus Namophila is closely related to Massonia according to the molecular study by Manning \& al. (2004). See Massonia for further comments on the classification of the group.

N. urotepala U. \& D. Müller-Doblies (Feddes Repert. 108(1-2): 77-79, ills., 1997). Type: Namibia, Witputz (Müller-Doblies 88064g [WIND, B, BOL, BR, BTU, E, G, K, LI, M, MO, NBG, PRE, S, Z]). — Lit: Martínez-Azorín \& al. (2015: with ills.). Distr: S Namibia (Witputz: S Namibian Escarpment); winterrainfall area, $\pm 700 \mathrm{~m}$, spring-flowering.

Description as for the genus.

\section{References}

Manning, J. C. [\& al. 2004], Goldblatt, P. \& Fay, M. F. (2004) A revised generic synopsis of Hyacinthaceae in sub-Saharan Africa, based on molecular evidence, including new combinations and the new tribe Pseudoprospereae. Edinburgh J. Bot. 60(3): 533-568, keys. https://doi.org/10.1017/ S0960428603000404

Martínez-Azorín, M. [\& al. 2015], Pinter, M. \& Wetschnig, W. (2015) Desertia, a new genus in Massonieae (Asparagaceae, Scilloideae), including the description of Desertia luteovirens and the taxonomic revisions of Whiteheadia and Namophila. Phytotaxa 221(3): 201-225, ills., maps, key. https://doi.org/10.11646/ phytotaxa.221.3.1

U. Eggli $(\bowtie)$

Sukkulenten-Sammlung Zürich, Grün Stadt Zürich,

Zürich, Switzerland

e-mail: Urs.Eggli@zuerich.ch 